\title{
In Memoriam: Steven Alec Weber
}

\author{
Steven D. Emslie ${ }^{1^{*}}$ \\ ${ }^{1}$ Department of Biology and Marine Biology, University of North Carolina, Wilmington, USA. \\ *emslies@uncw.edu
}

Received June 4, 2020

Accepted June 4, 2020

OPEN Ә ACCESS

Published June 28, 2020

DOI 10.14237/ebl.11.1.2020.1708

Copyright (C) 2020 by the author(s); licensee Society of Ethnobiology. This is an open-access article distributed under the terms of the Creative Commons Attribution-NonCommercial 4.0 International Public License (https://creativecommons.org/licenses/by-nc/4.0), which permits non-commercial use, distribution, and reproduction in any medium, provided the original author and source are credited.

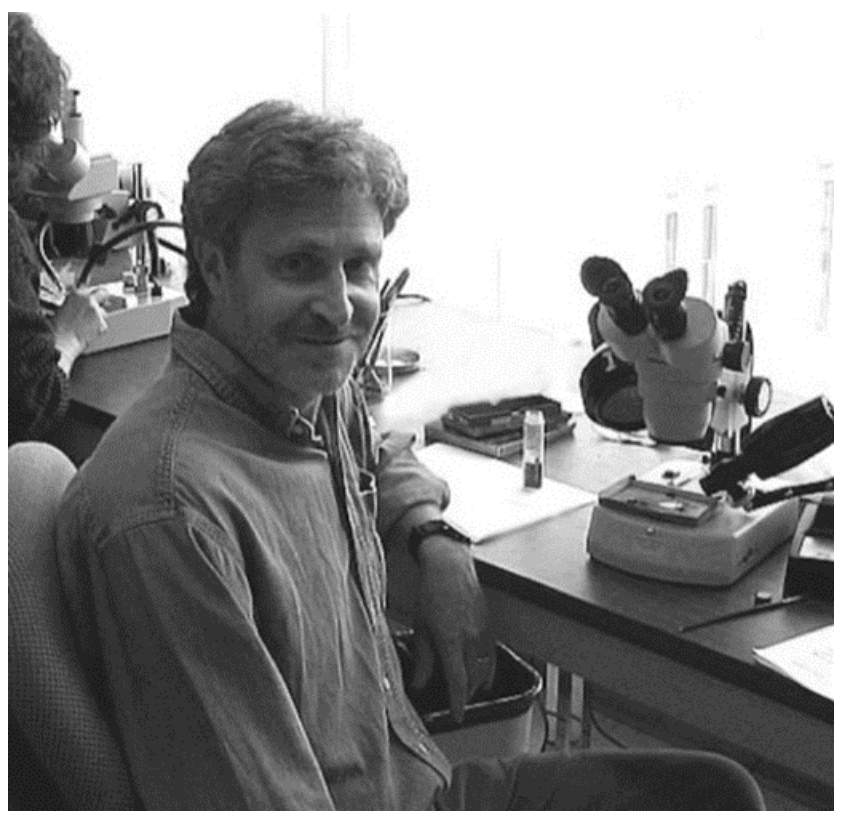

Steven Alec Weber passed away quietly and surrounded by family on January 14, 2020 from ALS, a disease he lived with for several years that he once described to me as a "new life experience." That characterization of a crippling disease accurately reflects Steve's upbeat personality. Not one to be overwhelmed or depressed by his condition, he embraced it and lived with it to the end, making the most of the time he had left.

Steve was born in San Francisco on March 4, 1954 and raised in Orinda, California. His interest in archaeology was piqued in 1969 by a year-long stay in Turkey with his family when they visited numerous archaeological sites. After graduating from Miramonte High School in 1972, he entered the Anthropology Department at Northern Arizona University (NAU) in 1973, graduating with his B.A. in 1976. As an undergraduate he worked on various field projects, including excavations at the Archaic Tuchness Site in eastern Arizona and an underwater palaeoindian site in Florida with Dr. Charles Hoffman. After graduating, he became a crew member for field surveys directed by contract archaeology offices at NAU and the Museum of Northern Arizona. By 1977, he was working for the Arizona State Museum on various survey and excavation projects, then was hired by Peter Pilles at the U.S. Forest Service, Coconino County, in March 1978, where we first met. Over the summer and by fall 1978, Steve developed a strong interest in ethnobotany and palynology and began working towards a Master's degree in the lab of Dr. Richard Hevly at NAU to extract pollen from archaeological soil samples, including those we had collected that summer at Elden Pueblo. It was also that summer when Steve and I began meeting for beers after work and when I learned what a great conversationalist he was, whether the topic was archaeology, biology, or politics. Steve would often begin a long discussion with a question, not one with a simple answer, but one that included deep thought on how to proceed in a given situation and how it might lead you to contradict your own beliefs. Thus, we formed a bond of friendship that lasted a lifetime.

In summer 1979, Steve went to Shasta-Trinity National Forest to be an archaeological technician for the McCloud District, California, where he completed surveys, wrote reports, and developed sampling designs for surveys and excavations. It was that summer when he lost his spleen, and very nearly his life, when a logging truck illegally passed him from behind as he was making a left turn. The truck 
smashed into the driver's side of the car, and it took Steve several months to fully recover, but he returned to Flagstaff that fall and continued his Master's research, graduating in July 1981 with a thesis titled "A Palynological Interpretation of the Sinagua and their Changing Environment” (Weber 1981).

During this same period, Steve and I initiated a business in Flagstaff in 1979 for archaeobotanical and zooarchaeological analyses for contract archaeologists. We also established a non-profit Society of Ethnobiology, with Steve as its first President, in 1981 to continue efforts to bring together ethnobiologists at annual conferences that I had been involved in initiating through Prescott Center College beginning in 1978. The history of these conferences and the subsequent establishment in 1981 of the Journal of Ethnobiology and the Society of Ethnobiology are fully described elsewhere (Emslie 2018). Steve then left to begin his Ph.D. in Anthropology at the University of Pennsylvania in fall 1982. Before he left, he had begun work editing his first book, Havasupai Habitat, an ethnography from A. F. Whiting's unpublished notes, that he co-edited with P. Seaman and was published by University of Arizona Press in 1985 (Weber and Seaman 1985).

Steve and I continued to meet at annual ethnobiology conferences over the next decade. He completed his Ph.D. in 1989 and began a teaching appointment as a Visiting Assistant Professor at Franklin and Marshall College. In 1994, he was hired as an Assistant Professor at Washington State University (WSU) Vancouver where he remained for the rest of his career. Throughout this time Steve had numerous accomplishments, the first in being awarded a Fulbright Scholar Award for research in Pakistan that led to his seminal work on Indus ethnobotany at Harappa (see d'Alpoim Guedes and Fuller 2018 for a review of this work). During his career, he published three books, 19 peer-reviewed papers, and numerous book chapters, while dividing his time between research and administrative duties. At WSU, Steve served as Associate Director of the College of Liberal Arts (2005-2006), Director of Research and Graduate Education (2006-2007), and Associate Chair of Anthropology (2008-2012). In 2017, he was recognized as a Distinguished Ethnobiologist by the Society of Ethnobiology at its 40th Annual Meeting. The fact that this society is still active and strong today is largely due to his leadership over the years. In 2017 a special symposium was held in his honor at the Annual Meeting of the Society for American Archaeology where many of his former students contributed papers. A special issue of the Journal of Ethnobiology was dedicated in his honor in 2018.

Up until his death, Steve remained active in his research and department and never wavered in his dedication to his students. In October 2019, when seriously ill, he made the effort to attend the defense of his last Ph.D. student at WSU. He has publications that are currently in press, while others will be submitted by co-authors in the near future. Steve never gave up and was productive to the end. When visiting him during this period, our long conversations continued and I will miss those the most. Once, when needing something to read at his house, I found a copy of writings by Marcus Tullius Cicero (2019) and read his essay "Laelius on Friendship" that I realized was a perfect eulogy for how I remember Steve:

... how could a life be "livable" which does not rejoice in the mutual good wishes of a friend? What is sweeter than to have someone with whom you dare to discuss everything, as if with yourself? How could there be great joy in prosperous things, if you did not have someone who would enjoy them equally much as you yourself? Disasters would be hard indeed to bear without someone who would bear them even more heavily than yourself. Finally, other things which are sought after are individual advantages for entirely individual things: riches that you may use them, resources that you may be looked after, honors that you may be praised, pleasures that you may enjoy them, health that you may be free from pain and make use of the gifts of the body; friendship contains very many things: wherever you turn, it is present, it is shut out from no place, is never unseasonable, never troublesome; thus we do not use water, we do not use fire, as they put it, in more contexts than friendship.

A fund in Steve's memory has been established by the Society of Ethnobiology at https://ethnobiology.org/ about/in-memory-steven-weber. 


\section{References Cited}

Ainana L. I., and I. Zagrebin. 2014. Edible Plants Used by Siberian Yupik Eskimos of Southeastern Chukotka Peninsula, Russia. National Park Service, Shared Beringian Heritage Program, Anchorage, AK.

Cicero, M. T. 2019. Laelius on Friendship [web page]. Wikisource, trans. Available at: https:// en.wikisource.org/wiki/

Translation:Laelius_on_Friendship. Accessed on June 16, 2020.

d'Alpoim Guedes, J., and D. Q. Fuller. 2018. Steven A. Weber: An Interdisciplinary Visionary in Paleoethnobotany. Journal of Ethnobiology 38:464 468. DOI:10.2993/0278-0771-38.4.464
Emslie, S. D. 2018. Steven A. Weber and the Birth of the Society of Ethnobiology. Journal of Ethnobiology 38:456-463. DOI:10.2993/0278-0771-38.4.456.

Weber, S. A. 1981. Palynological Interpretation of the Sinagua and Their Changing Environment. Unpublished Master's Thesis, Department of Anthropology, Northern Arizona University, Flagstaff, AZ.

Weber, S. A., and P. D. Seaman, eds. 1985. Havasupai Habitat: A. F. Whiting's Ethnography of a Traditional Indian Culture. University of Arizona Press, Tucson, AZ. 